\title{
Flowering Ecology of the Species of the Genus Hypoxidia (Hypoxidaceae: Asparagales)
}

\author{
Justin Gerlach \\ Nature Protection Trust of Seychelles, 133 Cherry Hinton Road, Cambridge CB1 7BX, UK \\ Correspondence should be addressed to Justin Gerlach, jstgerlach@aol.com \\ Received 18 July 2011; Accepted 14 August 2011 \\ Academic Editor: Karl Joseph Niklas \\ Copyright () 2011 Justin Gerlach. This is an open access article distributed under the Creative Commons Attribution License, \\ which permits unrestricted use, distribution, and reproduction in any medium, provided the original work is properly cited. \\ Hypoxidia (Hypoxidaceae) is endemic to the Seychelles islands. The two species H. rhizophylla and H. maheensis have rarely been \\ studied. The first studies of floral ecology are described based on 19 years of observations of cultivated (1992-1994) and wild \\ (1998-2011) plants of H. rhizophylla and a single flowering event of cultivated H. maheensis. In H. rhizophylla, heavy rainfall acts \\ as a trigger to flowering, with flowers opening 14 days after heavy rain. This can occur in any month and local rainfall can act as a \\ trigger even in generally dry conditions. Flowers are only open for a few hours, usually in the morning. Pollinators have not been \\ identified but only one specie has been seen visiting flowers regularly; the fly Dichaetomyia fasciculifera (Muscidae) is common on \\ Silhouette island where $12 \%$ of flowers are pollinated but very scarce on Mahé where fruiting of H. rhizophylla is rarely recorded. \\ Low rates of pollination and limited dispersal is thought to result in effective isolation of most populations which probably mainly \\ reproduce clonally. Clarification of this requires further research into genetic structuring of the populations.
}

\section{Introduction}

Hypoxidia is an isolated genus of the family Hypoxidaceae. It comprises two species, restricted to the Seychelles islands and forms a monophyletic Seychelles clade with the species "Curucligo" seychellensis [1]. The Hypoxidaceae have largely been overlooked in ecological studies due to the relatively small size and inconspicuous nature of most of the species. The Seychelles Hypoxidaceae are unusual in that they can be argued to form a major part of the forest ecosystems, being among the few herbaceous plants to be found in the closed woodlands of the larger Seychelles islands.

Hypoxidia rhizophylla (Baker) F. Friedmann is the most widespread of the Seychelles Hypoxidaceae, being recorded from Mahé, Silhouette, Praslin, La Digue, Curieuse, and Felicite $[2,3]$. On these islands it is rarely found below $150 \mathrm{~m}$ a.s.l. but can be found from sea level to $900 \mathrm{~m}$ a.s.l. (personal observation). In contrast, $H$. maheensis F. Friedmann is known only from most forests above $300 \mathrm{~m}$ on Mahé island. The two species differ in floral morphology and in some vegetative characters. $H$. rhizophylla is highly variable in leaf shape and size but always shows the ability to reproduce with epiphyllous buds. As a result it frequently forms what are probably clonal clumps. H. maheensis does not appear to form epiphyllous buds and has lower density populations. A high degree of geographical variation in floral characters has been observed in $H$. rhizophylla $[4,5]$, at least some of this variation appears to be genetic (being retained by cultivated plants), but whether these differences represent geographic genetic structuring or simply individual variation of clonal populations is not known. Similarly, the level of genetic diversity and gene flow between populations remains unstudied. Research on the genus has been largely restricted to taxonomy [5], phylogenetics [1], and morphology [68 ]. Ecological reports are limited to observations of their habitats $[5,9]$ and observation of synchronous flowering [10].

Here I report on observations of the flowering ecology of the two species accumulated over 19 years.

\section{Methods}

Flowering was studied in wild $H$. rhizophylla plants on Silhouette island (from 1998 to 2011) and in cultivated H. rhizophylla and $H$. maheensis plants in a domestic garden on 
Mahé (Le Niol, 250 m a.s.l.) from October 1992 to July 1994 (Figure 1). The wild plants were found in woodland from 20 to $700 \mathrm{~m}$ a.s.l. The main populations studied were between 150 and $300 \mathrm{~m}$ a.s.l. No attempt was made to count individuals, but it is estimated that the populations monitored numbered approximately 1,000 plants. The cultivated plants comprised four planted $H$. rhizophylla and one $H$. maheensis. All these plants were fully mature during the period of observation.

For both wild and cultivated populations a record was kept of all observation of flowering and seeding, and the identities of flower visitors. For the wild population a comparison was made between flowering dates and rainfall records from a permanent weather monitoring point at sea level (La Passe). The cultivated plants were watered on a weekly basis and therefore do not show natural seasonality in flowering, accordingly no comparison to rainfall was made for these plants.

\section{Results}

The cultivated $H$. rhizophylla flowered in every month except February and May, 1993. Flowering was recorded in the wild plants in all months (Figure 2) but with an irregular pattern which correlated to rainfall patterns. The main flowering events (when at least five flowers were observed in one day) occurred two weeks after rain. Single flowers were produced on other occasions that could not be connected to rainfall in the coastal weather monitoring site. There was a positive relationship between the number of flowers recorded and the amount of rain two weeks previously in the form of $y=3.453 x+6.33$ where $y=$ rain 14 days before flowering, $x=$ number of open flowers $\left(R^{2}=0.435, P<0.05\right]$.

Wild flowers usually opened in the morning and cultivated flowers opened before 9:00 am (Figure 3). Flowering finished (at least half of the petals closed over the flower) by 12:15. On one occasion (out of 50) a flower opened in the night and had closed by 8:30 am.

Most of the cultivated plants produced flower stems with multiple (2-3) buds, these opened over the course of 2-3 days (only one flower open on each plant at any one time). Wild flowers were single or double, rarely with three flowers on a stem. The number of flowers varied geographically (Figure 4).

Flower visitors were rarely observed; on the wild plants the muscid fly Dichaetomyia fasciculifera was observed visiting open flowers on five occasions. No other potential pollinators were observed. Only two cultivated flowers were visited by animals; one was visited by an unidentified sarcophagid fly and one by an ant (Camponotus grandidieri) and a small weevil. None of the cultivated flowers were pollinated. Pollination is also infrequent in the wild flowers; of 100 flowers only 12 set seed.

The single $H$. maheensis plant formed flower buds in June 1994, it took 11 days for the first flowers to open (two on the same day), with a third flower the following day. These flowers did not open fully, with half the petals remaining vertical.

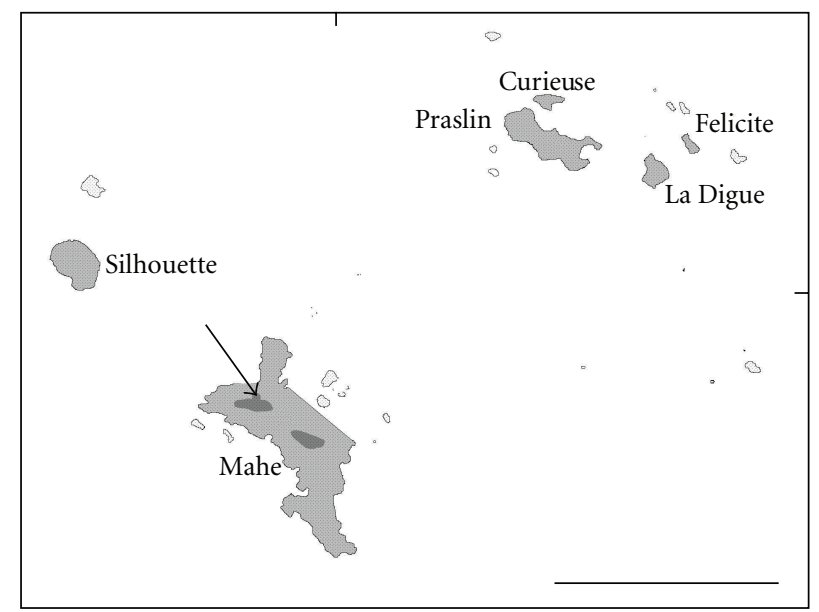

FIGURE 1: Map of study areas. Islands occupied by Hypoxidia rhizophylla, labelled and shaded. Approximate range of $H$. maheensis, dark shaded. Location of Le Niol study site marked by an arrow. Scale bar $20 \mathrm{~km}$.

\section{Discussion}

From the observations reported here it appears that flowering in Hypoxidia rhizophylla is stimulated by rainfall. Occasional production of single flowers may occur at any time of year, possibly in response to local rainfall but large scale flowering is triggered by increases in rainfall. Heavy rain showers stimulate bud development and flowers may open 12 days after rain. This results in a frequent synchronous pattern of flowering [10]. For H. maheensis there are insufficient data to determine whether or not the same pattern occurs. Mass flowering has been recorded in other Hypoxidaceae, but in the case of Hypoxis sessilis and H. wrightii in Florida this is triggered by fire [11].

Pollination is infrequent in $H$. rhizophylla, with $12 \%$ of flowers setting seed on Silhouette island. Unquantified observations on Mahé suggest that pollination is less frequent on that island [12]. The only regular flower visitor to H. rhizophylla was the muscid fly Dichaetomyia fasciculifera. However, this was examined to determine whether or not it was acting as a pollen vector and it must still be considered a potential pollinator. This fly is highly abundant in the forests of Silhouette but is scarce on Mahé (personal observation). The pollination of Hypoxidia has long been speculated to be sapromyophilous on the basis of the commonly red-brown flowers and the rotting odour emitted by the open flowers [4]. Myophily has been reported in Hypoxis decumbens [13] and is probably frequent in Hypoxidaceae. Friedmann [4] reported regular fruiting and thought that $H$. rhizophylla was probably self-fertile. The low levels of pollination recorded here indicate that this is unlikely. Experimental pollination studied need to be undertaken to establish the frequency of self-pollination.

The mechanism of seed dispersal in Hypoxidia is not clear. The fruit pod is fibrous and although its surface is often grazed by molluscs there is no evidence of any animal dispersal of seeds. Pods dried artificially are dehiscent but not 


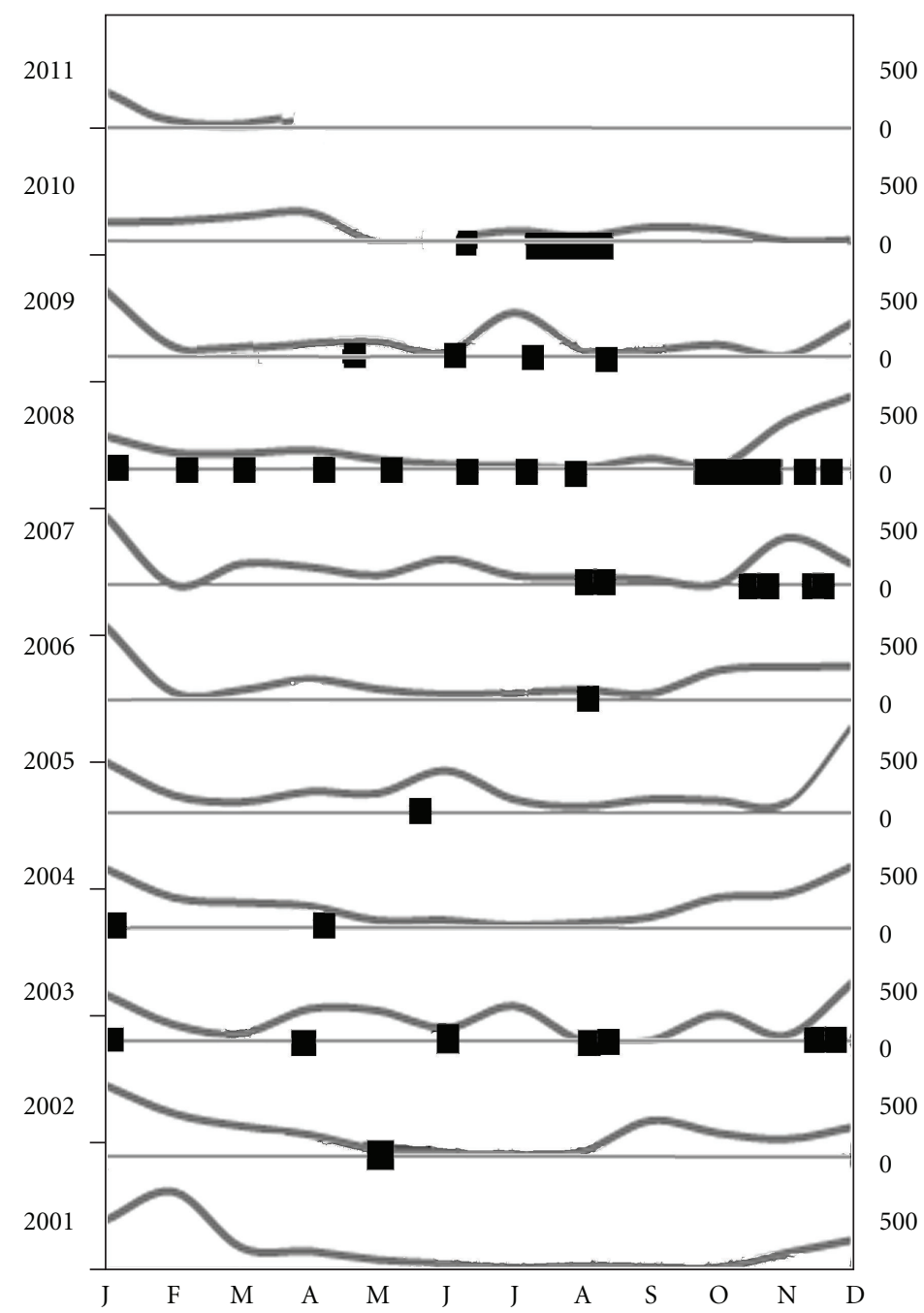

FIGURE 2: Phenology of wild Hypoxidia rhizophylla on Silhouette island in 2001-2011. Black bars: flowering, lines: rainfall (right hand scale in $\mathrm{mm}$ ).

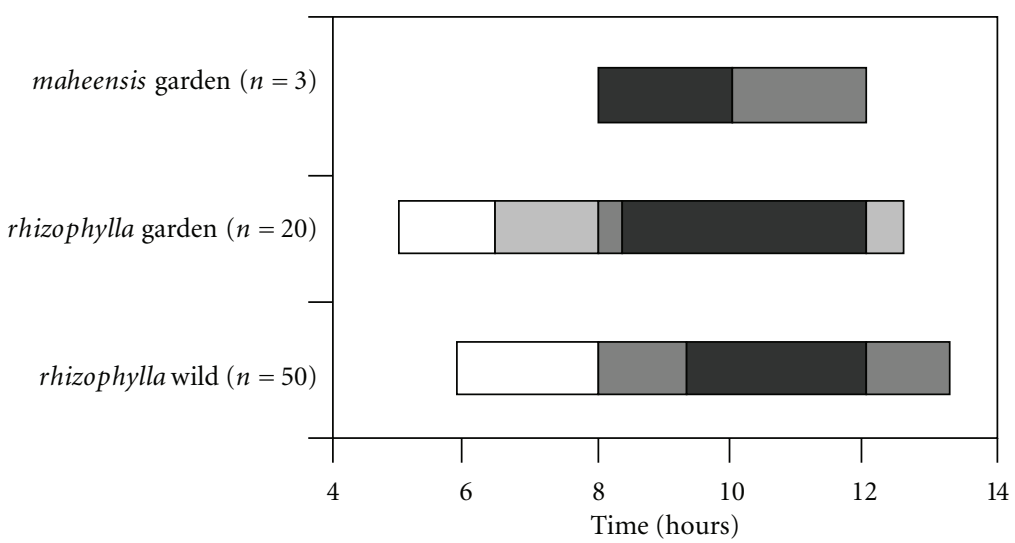

FIgURE 3: Temporal pattern of flower opening in Hypoxidia. Black: all flowers observed; dark grey $>50 \%$; pale grey $50-5 \%$ of flowers; white $<5 \%$. 


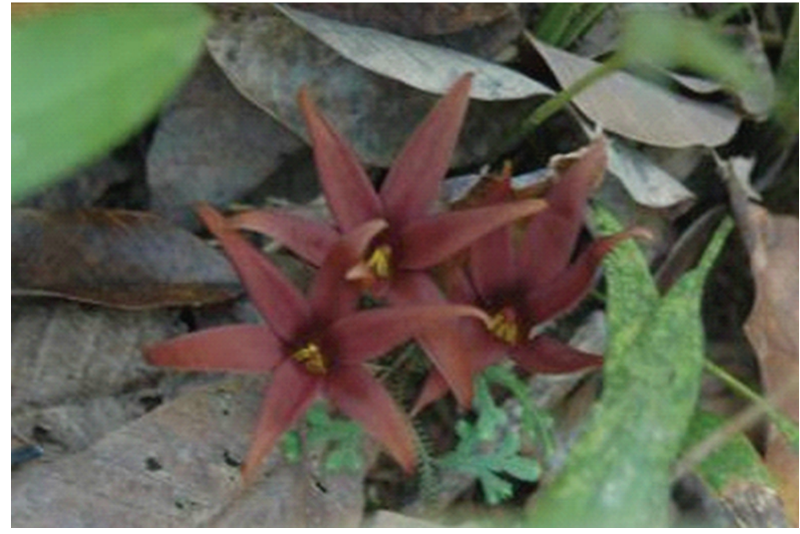

(a)

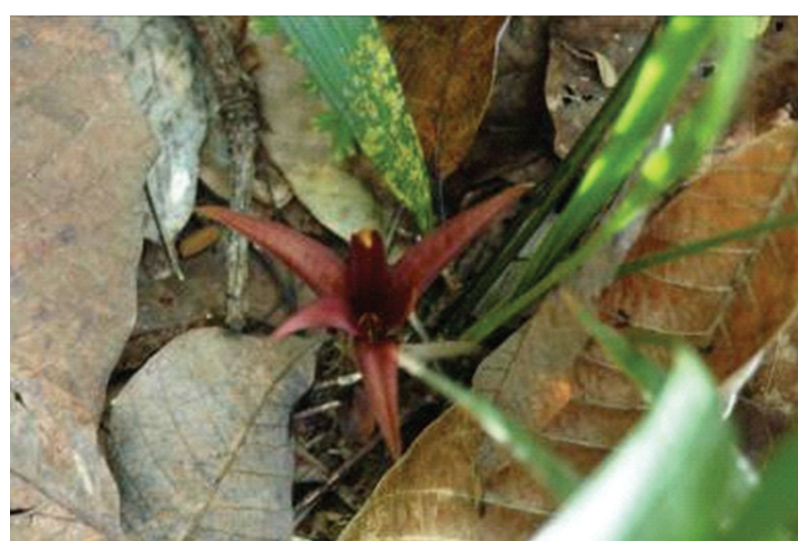

(b)

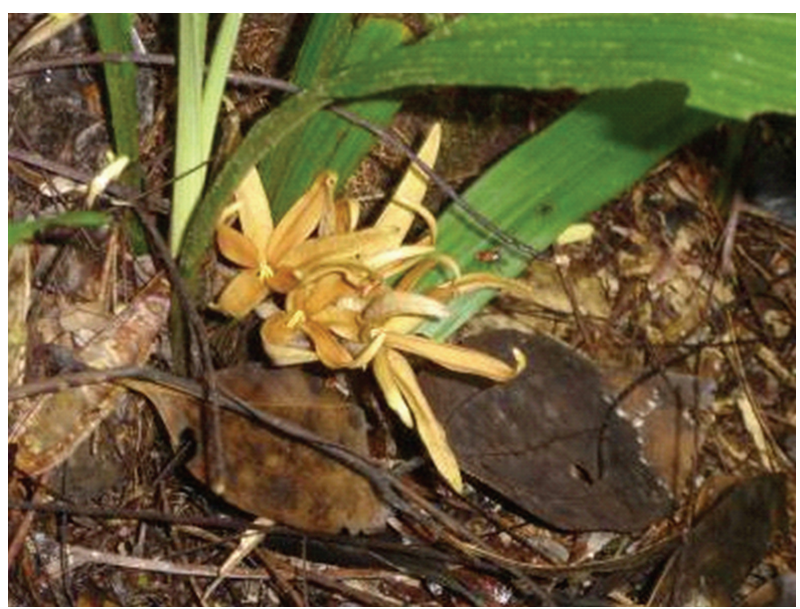

(c)

FIgURE 4: Variation in flowers on Silhouette. (a) Triple maroon flowers; (b) single maroon flower; (c) triple ochre flowers.

explosive. Thus it seems probable that the seeds are released onto the ground and dispersal is normally very limited. Release of seeds onto the soil surface at the base of the parent plant is reported to lead to myrmecochorous dispersal in Hypoxis decumberns. No close association with ants has been observed with Hypoxidia, and it is possible that heavy rainfall could move the seeds away from the parent plants without the need for active dispersal.

The significant levels of geographical variation in petal colour, shape, and size in H. rhizophylla [5] suggests that there is a high level of genetic structuring of population. The limited seed dispersal suggests that gene flow is primarily through pollination. The low level of successful pollination indicates that gene flow will be limited. Most successful reproduction appears to be as a result of epiphyllous budding. As a result most populations will have very little genetic variation. Lacking the ability to reproduce clonally, H. maheensis may be even more restricted unless it has higher pollination rates. Studies of the genetic diversity and population structure of these two species would be highly desirable.

\section{References}

[1] A. Kocyan, D. A. Snijman, F. Forest et al., "Molecular phylogenetics of Hypoxidaceae-evidence from plastid DNA data and inferences on morphology and biogeography," Molecular Phylogenetics and Evolution, vol. 60, no. 1, pp. 122-136, 2011.

[2] S. A. Robertson, Flowering Plants of Seychelles, Royal Botanic Gardens Kew, UK, 1989.

[3] M. J. Hill, D. R. Currie, T. M. Vel, and R. Fanchette, "Felicite," Atoll Research Bulletin, vol. 495, no. 7, pp. 119-140, 2002.

[4] F. Friedmann, "Note sur les Hypoxidaceae des Seychelles et description du genre nouveau Hypoxidia," Bulletin du Muséum National d'Histoire Naturelle Section B, vol. 4, pp. 453-460, 1984.

[5] F. Friedmann, Flowers and Trees of Seychelles, Editions de l'Orstom, Paris, Farnce, 1986.

[6] L. Penet, S. Nadot, A. Ressayre, A. Forchioni, L. Dreyer, and P. H. Gouyon, "Multiple developmental pathways leading to a single morph: monosulcate pollen (examples from the asparagales)," Annals of Botany, vol. 95, no. 2, pp. 331-343, 2005.

[7] L. Penet, M. Laurin, P.-H. Gouyon, and S. Nadot, "Developmental constraints and selection: insights from microsporogenesis in Asparagales," Evolution and Development, vol. 9, no. 5, pp. 460-471, 2007.

[8] S. Nadot, A. Forchioni, L. Penet, J. Sannier, and A. Ressayre, "Links between early pollen development and aperture pattern in monocots," Protoplasma, vol. 228, pp. 55-64, 2006.

[9] R. Wise, A Fragile Eden, Princeton University Press, Princeton, NJ, USA, 1998.

[10] R. Gerlach, "A note on synchronous flowering of Hypoxidia rhizophylla (Baker, 1874)," Phelsuma, vol. 10, p. 53, 2002.

[11] A. Herndon, "Ecology and systematics of Hypoxis sessilis and H. wrightii (Hypoxidaceae) in Southern Florida," American Journal of Botany, vol. 75, no. 12, pp. 1803-1812, 1988.

[12] Anon, "Notes from the field," Kapisen, vol. 10, p. 19, 2010.

[13] E. Raimúndez and N. Ramírez, "Reproductive strategy of a perennial herb: Hypoxis decumbens (Hypoxidaceae)," Revista de Biologia Tropical, vol. 46, no. 3, pp. 555-565, 1998. 

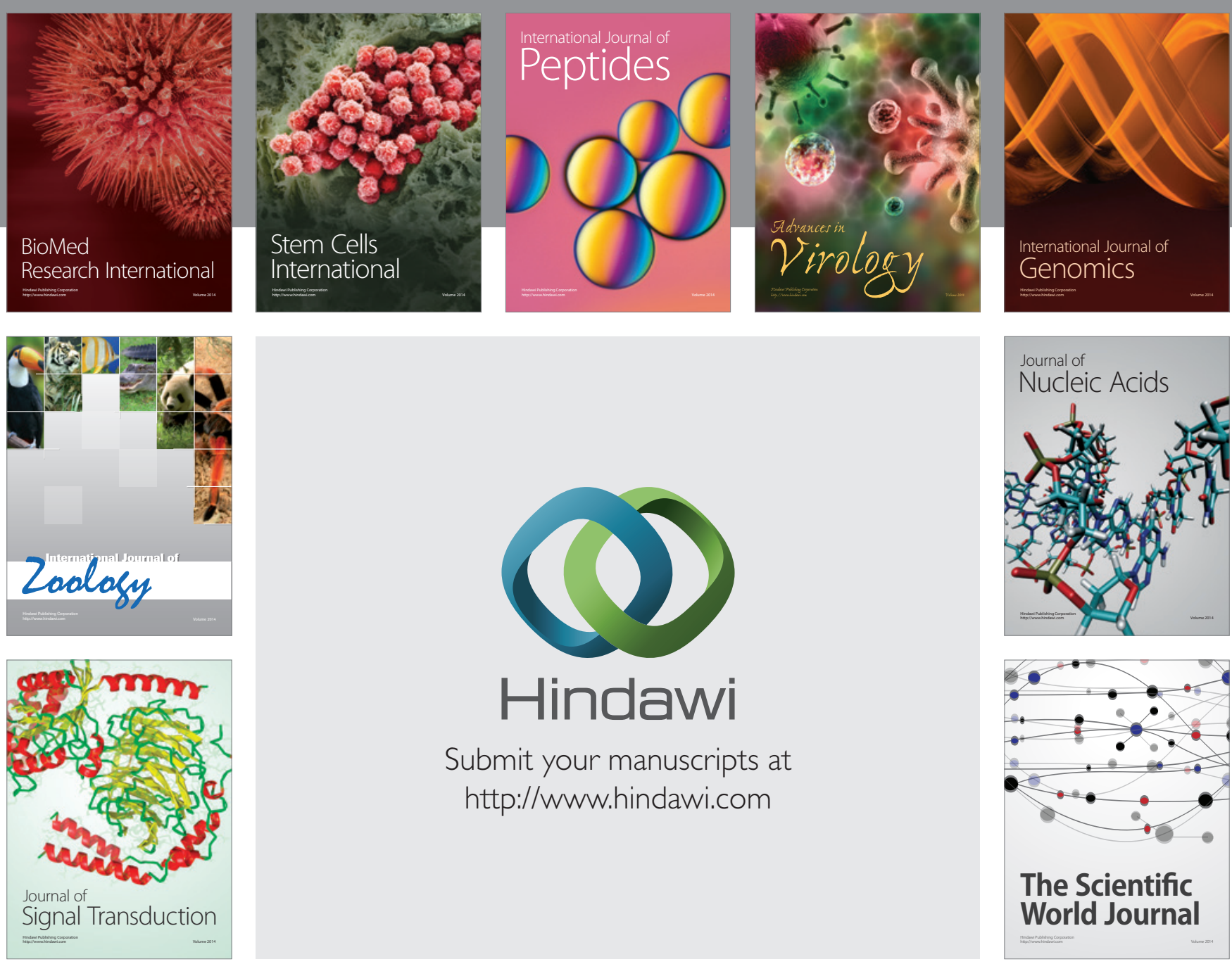

Submit your manuscripts at

http://www.hindawi.com
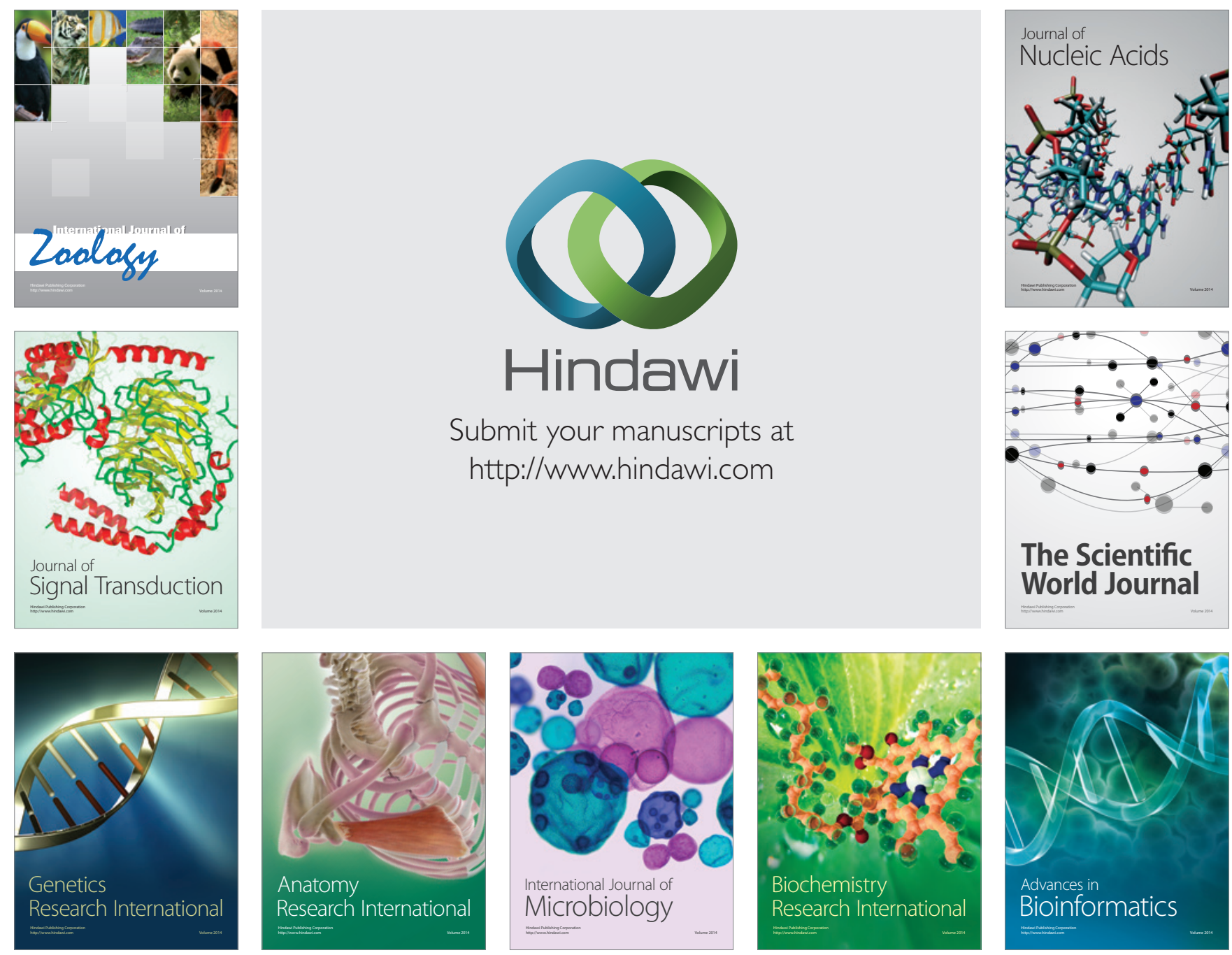

The Scientific World Journal
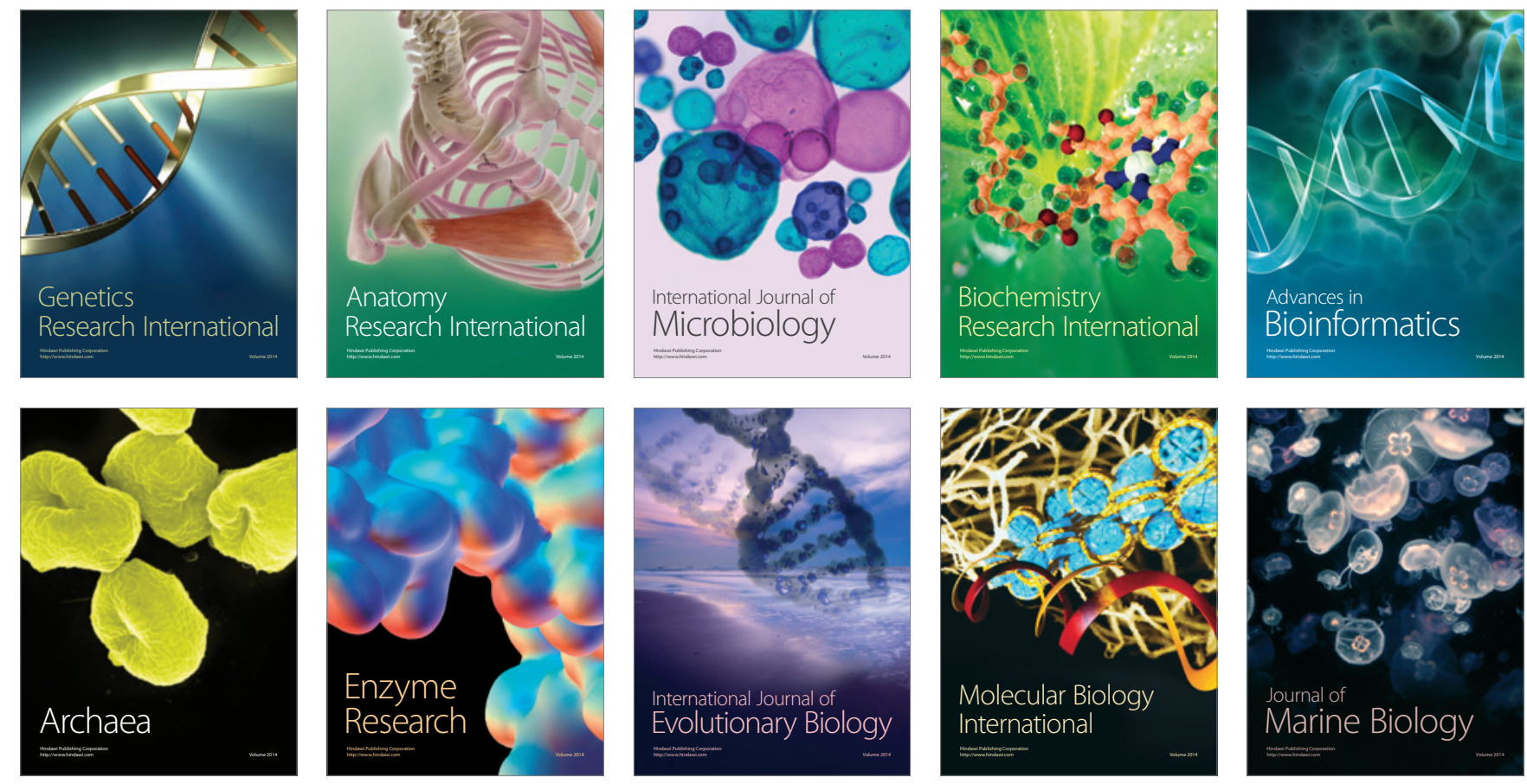